\title{
Analysing the impact of the double taxation treaty on foreign direct investment in Indonesia
}

\author{
A. Rizky \& C. Tjen \\ Department of Accounting, Faculty of Economics and Business, Universitas Indonesia, Depok, Indonesia
}

\begin{abstract}
Foreign Direct Investment (FDI) is an important element in the era of globalisation and links between economies. Agreement between partner countries, particularly on the avoidance of double taxation, is believed to contribute to increasing flows of FDI. This study aims to examine whether agreements on the avoidance of double taxation have an effect on FDI and to discover what other factors have an influence on FDI in Indonesia. This study uses a number of data samples of double taxation treaties in Indonesia with partners from developed countries within the period from 1990 to 2014. Data processing uses the OLS regression analysis with time series data structure. The result of this study shows that an avoidance of double taxation treaty increases the flow of FDI into Indonesia. In addition, GDP per capita, resources rent and political conditions also affect FDI in Indonesia. Among these influencing factors, the treaty on the avoidance of double taxation has been the main factor that has had the most influence on FDI in Indonesia.
\end{abstract}

\section{INTRODUCTION}

Developing countries often use bilateral agreements as a signal of their commitment to foreign investors. Their aim is to increase the flow of FDI into developing countries. By signing the double taxation agreement, developing countries will ensure stability and security for foreign investors on the issue of double taxation. In addition to signing a double taxation treaty, developing countries have also signed a bilateral investment treaty. This has been done to demonstrate the commitment from developing countries to give equal treatment to both local and foreign investors in the regulations and standards (Neumayer, 2007).

Global FDI in 2014 declined by 16\% compared to 2013, and in 2013 the value reached 1.47 billion USD to 1.23 billion USD in 2014. Several factors led to a decline in 2014, including global economic conditions that were less stable, policy uncertainty for investors and the emergence of geopolitical risks in some places in the world. FDI flow to developed countries fell by $28 \%$ to 499 billion USD and the flow of FDI to economic transition countries fell by $52 \%$ to 48 billion USD. While FDI flow to developing countries increased by $2 \%$ to 681 billion USD, see Figure 1, this was driven by the flow of FDI to developing countries in Asia (UNCTAD, 2015).

FDI flow to the continent of Asia increased by $9 \%$ in 2014 to 465 billion USD, as East Asia, Southeast Asia and South Asia experienced an increase in receiving FDI flow. Only the West Asia region has continued to show a downward trend over a period of 6 years. In 2014, the West Asia region only received FDI flow amounting to 43 billion USD, and this is because of the unstable security situation in the region. China received FDI flow amounting to 129 billion USD in 2014, which increased by 4\% compared to 2013. The service sector became the main support for China's growth. An increase in FDI flow also occurred in Hong Kong, Singapore, India and Indonesia, see Figure 2 (UNCTAD, 2015).

In the period from the $1960 \mathrm{~s}$ to the $2000 \mathrm{~s}$, Indonesia made many agreements with developed countries, both bilateral investment treaties and double taxation treaties. This was done by the Indonesian government in order to improve the attractiveness of investment in Indo- 


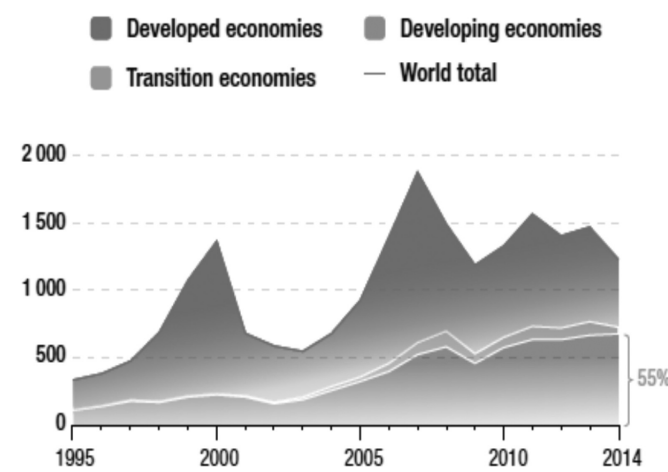

Figure 1. Trend of FDI flow from the years 1995-2014 (in billion USD). Source: UNCTAD (2015).

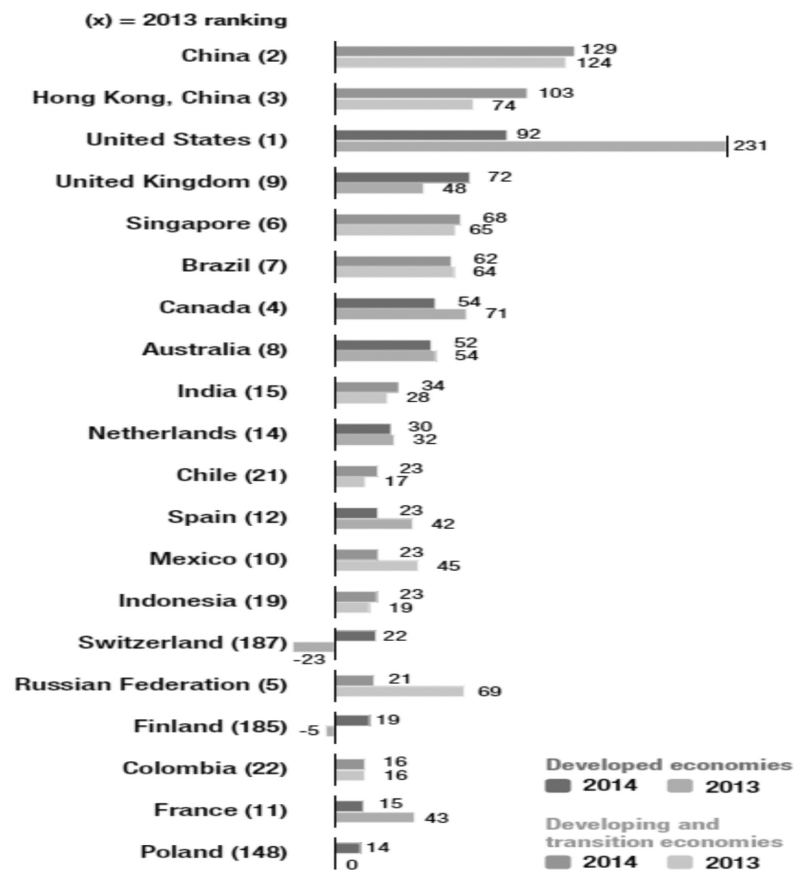

Figure 2. The 20 countries with the largest FDI flow in 2013-2014 (in billion USD). Source: UNCTAD (2015).

nesia, as well as providing certainty in the field of law and taxation. With many foreign investors investing directly in Indonesia, this will generally result in increasing the overall Indonesian economy. In 2015 President Joko Widodo revised the bilateral investment treaty, which is not considered relevant in the current economic conditions. Things that would be revised in bilateral investment treaty agreements include an expiration date, automatic renewal of the agreement and equal conditions for both countries (Ariyanti, 2015).

The double taxation treaty in Indonesia is called P3B or an agreement on the avoidance of double taxation. P3B allegedly has the effect of raising the flow of FDI, as the results of several previous studies support this contention, however, several other studies have concluded that there is no effect between FDI and P3B (Badan Kebijakan Fiskal, 2012). According to the Badan Kebijakan Fiskal (2012), "P3B is the agreement made by two/more countries/tax 
jurisdictions governing the tax treatment of income tax on income earned by the domestic taxpayer". This agreement relates to the passive income of the beneficial owner. Tax problems arise when the two countries want to impose a tax on the same kind of income. Some of the desired goals of the Indonesian government in making P3B with partners from other developing countries, as well as with developed countries, are namely: the loss of double taxation, the increase in foreign investment, human resources development, the exchange of information between the tax authorities to fight tax evasion and fair conditions on taxation between P3B partners (Badan Kebijakan Fiskal, 2012).

\section{LITERATURE REVIEW}

According to the research from Rahayu (2008), FDI is one indicator of the economic system in the era of globalisation today. FDI comes from a company in one country investing over a long period of time in companies from other countries. The company may have either partial or full control over the company that is in another country. The majority of the forms of FDI lead to full control over a company. Easson (2000) argues that the forms of foreign investment may be the transfer of assets to the state's investment objectives, investing back in the country of investment, buying assets in an investment destination country, as well as the acquisition of the majority of shares or providing loans to subsidiaries or affiliated companies (Rahayu, 2008).

The FDI flow to Indonesia can come in two ways, according to Gunadi (1997). First, to establish a subsidiary, we could create a new body called a PT. PMA (Foreign Investment Company), or we could buy a majority company's shares in Indonesia that is already in operation. These subsidiaries have a legal standing as being separate from their parent company, although the sources of capital and the control of the business are conducted by the parent company. From a fiscal standpoint, transactions can be made between the two for the value used in fair transactions because they have a special relationship. The second way is by setting up a branch company. A foreign branch company is, in fact, a division that is operated in a separate geographical area. From a legal point of view, as well as for taxes, the branch company and headquarters are a single entity. The establishment of a branch company will create BUT (Permanent Establishment), while the establishment of a subsidiary will be treated as a domestic taxpayer (Rahayu, 2008).

The conventional view of tax practitioners and tax authorities stated that tax treaties will attract foreign investment. Economists also argue that tax treaties will increase investment because tax treaties indicate the co-operation towards taxation between treaty partners. How can it happen? First, the harmonisation of the definition of taxes and tax jurisdiction between treaty partners would reduce double taxation on investment. For example, the income is taxed by the state as the source of income is derived from permanent establishments (BUT), and the definition of the BUT is set up very clearly in the tax treaties. If there is no agreement between the two countries, then there is a possibility that the definition of the BUT will be different and this will lead to double taxation on that income. Second, tax treaties have an effect on taxation carried out by a multinational company. This may occur because of the mechanisms of double taxation system either the credit system or the exemption and the withholding taxes on income derived from foreign affiliated company such as dividends, interest, and royalties. With the tax treaties, the tax rate on such income will drop, which will cause the tax burden of companies to also decline, and this is expected to increase the company's investment abroad. Developing countries often act as an importer of capital. Therefore, in their tax treaties with partners from developed countries, developing countries act as a source country, while the developed countries act as the state of domicile. The application of tax treaties, when the tax can be levied by the source state, is reduced, which is actually reducing tax revenues from developing countries. Discussion of tax treaties in developed countries as exporters of capital, largely driven by multinational companies originating from these countries. Like, the motivation to create a new treaty or modify an existing treaty. For example, tax treaties between Mexico and Indonesia were encouraged by the national oil 
company Pemex, which allowed the Mexico oil industry to invest in Indonesia. Furthermore, the tax treaties between the United States and the Netherlands are triggered by the investment company Shell and Philips (Loncarevic, 2005).

From an economic standpoint, the presence of double taxation would provide a greater burden on the business activity, investment and other activities, which would cause a disruption of the flow of resources between countries that work together. To overcome this, most of the tax authorities in the world work together and make agreements to avoid double taxation. Surrey (1980) provides a definition of double taxation treaties, namely the agreement made by two or more countries, which aims to find a way out of double taxation (Sophia, 2013).

Until 2015, Indonesia had had double taxation agreements with 65 partner countries. The agreements focused only on income tax. The position of Indonesia's double taxation treaty also embraced aspects of international law. So if the agreement on the avoidance of double taxation (P3B) has already been effective, then this may change the tax subject or tax object that has been determined in the domestic tax laws of Indonesia (Sophia, 2013). Indonesia's legal basis enables it to make a double taxation treaty (Sophia, 2013):

1. Article 11 paragraph 1 of the Constitution of 1945.

In this chapter, it is mandated that the President can make treaties with other states with the consent of the House of Representatives.

2. Article 4 paragraph 1 of Law No. 24 of 2000.

This law regulates an international agreement by Indonesia with other countries. This article states that the conclusion of a treaty should be based on the agreement, and the parties involved are obliged to implement it in good faith.

3. Section 32 A of the Income Tax Act No. 7 of 1983, as amended into the Law No. 36 of 2008. This Article provides that, in order to avoid the incidence of double taxation and prevent tax evasion, the government has the authority to make agreements with other countries.

Research conducted by Neumayer (2007) aimed to discover whether the United States' double taxation treaty with partners from developing countries would increase FDI to developing countries. His research shows that developing countries that have a tax treaty with the United States have benefited by getting a higher flow of FDI, compared to the developing countries that do not have a double taxation treaty with the United States. Several other previous studies that discuss the relationship between the tax treaty and FDI can be seen in Table 1.

Table 1. Previous studies on treaty and FDI.

\begin{tabular}{|c|c|c|c|}
\hline Research information & Samples & Type & Result \\
\hline Davies, 2003 & US treaty network, 1966-2000 & Dyadic studies & No effect on FDI \\
\hline $\begin{array}{l}\text { Bloningen \& } \\
\text { Davies, } 2004\end{array}$ & $\begin{array}{l}\text { US inward and outward } \\
\text { investment stocks in term } \\
\text { of } 88 \text { partners, } 1980-1999\end{array}$ & Dyadic studies & No effect on FDI \\
\hline $\begin{array}{l}\text { Bloningen \& } \\
\text { Davies, } 2005\end{array}$ & $\begin{array}{l}\text { OCED data on bilateral } \\
\text { FDI stocks and flows, } \\
\text { 1982-1992 }\end{array}$ & Dyadic studies & No effect on FDI \\
\hline $\begin{array}{l}\text { Egger et al., } \\
\quad 2006\end{array}$ & $\begin{array}{l}\text { Bilateral outward FDI from } \\
\text { OECD source countries, } \\
\text { 1985-2000 }\end{array}$ & Dyadic studies & No effect on FDI \\
\hline Giovanni, 2005 & 193 countries, 1990-1999 & Monadic studies & Increase FDI \\
\hline $\begin{array}{l}\text { Barthel et al., } \\
2010\end{array}$ & $\begin{array}{l}30 \text { FDI source countries and } \\
105 \text { FDI host countries, } \\
1978-2004\end{array}$ & Monadic studies & Increase FDI \\
\hline $\begin{array}{l}\text { Coupe, Orlova } \\
\text { and Skiba, } \\
2008\end{array}$ & $\begin{array}{l}\text { Investment from OECD } \\
\text { countries to } 9 \text { transition } \\
\text { economies, 1999-2001 }\end{array}$ & Monadic studies & $\begin{array}{l}\text { No consistent } \\
\text { findings }\end{array}$ \\
\hline
\end{tabular}

Source: www.dannydarussalam.com. 
Table 2. Variable data sources.

\begin{tabular}{ll}
\hline Symbol & Data source \\
\hline FDI & World Bank, BKPM \\
P3B & www.dannydarussalam.com \\
GDP & World Bank, BI \\
Population & World Bank, BPS \\
Economic Growth & World Bank, BI \\
Inflation & World Bank, BI, BPS \\
Resource Rents & World Bank \\
Trade & World Bank \\
Politic Condition & www.systemicpeace.org \\
\hline
\end{tabular}

\section{RESEARCH METHOD}

The research approach used in this study is a quantitative research approach, which uses multiple linear analysis regression to analyse the effect of double taxation treaties in Indonesia on FDI into Indonesia. The measurement results of this study will be used as an evaluation of the Indonesian government in making decisions related to agreements with partner countries on the avoidance of double taxation in Indonesia.

The data used in this research are the data from the P3B in Indonesia with partners from the developed countries within the period of 1990 to 2014. The definition and grouping of developed countries was taken from the 2016 World Bank Development Indicator Data. The data used in this study are time series and secondary data. Data were collected from the literature and from studies. See Table 2 for the data source variables used in this study.

This study uses two types of variables, an independent variable and a dependent variable. An independent variable is a variable whose movement is not affected by the dependent variable. A dependent variable is a variable whose motion is affected by the independent variable. The independent variables are divided into two: explanatory variables and control variables (Neumayer, 2007).

The model of this study is:

$$
\mathrm{Y}=\beta_{\mathrm{o}}+\beta_{1} \mathrm{X}_{1}+\beta_{2} \mathrm{X}_{2}+\beta_{3} \mathrm{X}_{3}+\beta_{4} \mathrm{X}_{4}+\beta_{5} \mathrm{X}_{5}+\beta_{6} \mathrm{X}_{6}+\beta_{7} \mathrm{X}_{7}+\beta_{8} \mathrm{X}_{8}+\varepsilon \tau
$$

where

$\mathrm{Y}=\mathrm{Log}$ of Total Foreign Direct Investment Flows into Indonesia

$\mathrm{X}_{1}=$ Cumulative Number of P3B Signed with Developed Countries, Weighted by the Number of Inward FDI Flow to Indonesia Relative to Total World FDI Flow.

$\mathrm{X}_{2}=$ Log of GDP per Capita Indonesia

$\mathrm{X}_{3}=\mathrm{Log}$ of Total Indonesia Population

$\mathrm{X}_{4}=$ Economic Growth

$\mathrm{X}_{5}=$ Inflation

$\mathrm{X}_{6}=$ Resources Rent (\% of GDP)

$\mathrm{X}_{7}=$ Trade $(\%$ of GDP)

$\mathrm{X}_{8}=$ Politic Condition

$\beta_{\mathrm{o}}=$ Constant

$\beta_{1-}$ to $\beta_{8}=$ Regression Coefficients

$\varepsilon_{\tau}=$ Error

\section{RESULTS}

The $\mathrm{R}$ square (adjusted $\mathrm{R}$ square) is very useful for measuring the affinity between the predicted value and the actual value of the dependent variable. The larger the $\mathrm{R}$ square, the greater the relationship between a dependent variable and one or more independent variables. 
In order to meet the criteria for an optimal fashion, the criteria in Table 3 must meet the criteria of optimal models, namely:

By looking at the output above, the regression model of this study suggests optimal results, because it:

- Has a high value of adjusted $\mathrm{R}^{2}$, which means that the variations of the five independent variables of this model, namely P3B, GDP per capita, Resources Rent, Politics and Trade, are able to explain the FDI as the dependent variable of $87.80 \%$, while the rest of the $12.20 \%$ is explained by other factors that are not included in the research model.

- Has a value of F-statistics less than 5\%.

- Has a value of Akaike Information Criterion (AIC) that is relatively low at -0.198242 .

- Carries Schwarz Information Criterion (SIC) that is relatively low at 0.100477 . This shows the simplicity of the model.

Looking at the results from Table 4, we can conclude which variables have a level of significance below 0.05 and can be used in the research model to describe the factors that influence FDI in Indonesia. From the results of the regression that has been made to the existing variables, the equation model is obtained as follows:

$$
\text { FDI }=14 \text { P3B }+2.18 \text { GDPpc }+7.872 \text { Resources Rent }-0.04 \text { Politics }
$$

The overall independent variables provide a positive effect on the increase in the flow of FDI, except for the political variables, which have a negative correlation. From the above equation model, we can interpret that the addition of double taxation treaties (P3B) will make an impact of $14 \%$ for every $1 \%$ increase in FDI.

Indonesia has double taxation treaties with developed countries, which could allow Indonesia to receive a greater direct investment flow when compared with other developing countries that do not have a tax treaty agreement with these countries.

From Figure 3 it can be seen that when there is the addition of double taxation treaties, the FDI into Indonesia will increase, except during a period of economic crisis. This study shows that there is a strong correlation between the addition of double taxation treaties and the increase in FDI into Indonesia. Indonesia, which serves as a source country, will keep investors from their partners in developed countries interested in investing in Indonesia. In terms of the signing of the double taxation treaty, Indonesia made a deal with many countries in the period from the $1990 \mathrm{~s}$ to the $2000 \mathrm{~s}$. This is also consistent with the results of this study, which show that the addition of double taxation treaties, especially with partners in developed countries, will increase the flow of investment from foreign investors. These

Table 3. Coefficient of determination results.

\begin{tabular}{ll}
\hline Criteria & Value \\
\hline R squared & $91.01 \%$ \\
Adjusted R squared & $87.80 \%$ \\
Prob (F-statistic) & 0.000001 \\
Akaike info criterion & -0.198242 \\
Schwarz criterion & 0.100477 \\
\hline
\end{tabular}

Table 4. Hypothesis testing results.

\begin{tabular}{lcll}
\hline Independent variable & Coefficient & Significance level & Decision \\
\hline P3B & 14 & 0.0172 & Reject Ho \\
GDP per Capita & 2.182 & 0.0021 & Reject Ho \\
Resources Rent & 7.872 & 0.0029 & Reject Ho \\
Politics & -0.04 & 0.0252 & Reject Ho \\
Trade & 0.454 & 0.7569 & Accept Ho \\
\hline
\end{tabular}




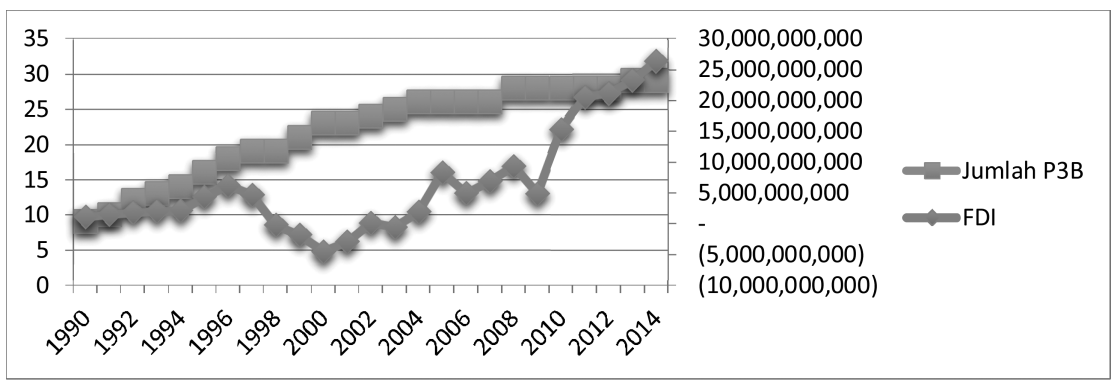

Figure 3. FDI trend \& number of P3B with developed countries.

results are also consistent with the results from Neumayer (2007), which show that developing countries that have double taxation treaties with more developed countries are benefited by getting a higher flow of FDI. In addition, the results of this study are also in tune with economists, who argue that tax treaties will increase investment because tax treaties indicate the co-operation in taxation between treaty partners. Thus, it can be concluded that there is a correlation between P3B and FDI.

On the control variables, gross domestic products per capita will make an impact of $2.18 \%$ for every $1 \%$ increase in FDI, and the resources rent will have an impact of $7.87 \%$ for every $1 \%$ increase in FDI. As for the political situation, it will have an impact of $0.04 \%$ for every $1 \%$ decrease in FDI. Indonesia is a capital importer country that has a large GDP, reserves of natural resources in oil, gas and mining, and has stable political conditions, so it will get an opportunity to have a higher inflow of FDI because investors also look at these three aspects in determining their decision on whether or not to invest in Indonesia.

If the total number of mineral resources rents in Indonesia is higher, then the FDI into Indonesia will also increase. However, it is also influenced by the technical factors of the fields or wells of mineral resources that Indonesia has. Foreign investment flow to Indonesia has continued to increase during the last fifteen years. This is supported because of the improved condition of Indonesia's economy and more stable political conditions. During Indonesia's economic crisis of 1997-1998, which was followed by political and security instability, much foreign investment flow went out of Indonesia.

Thus, when the GDP per capita of Indonesia continues to increase, it is expected that this will give a signal to investors that the economic situation in Indonesia is very good, which will create a conducive business climate. This will encourage foreign investors to invest in Indonesia, which, in turn, will increase the flow of FDI into Indonesia. Thus, it can be concluded that in terms of both mineral resources and political and economic conditions, they affect the increase in FDI in Indonesia, which is in line with the results of this study.

\section{CONCLUSION}

The avoidance of double taxation agreement (P3B) significantly affects the flow of FDI into Indonesia. This is consistent with the conventional view of tax practitioners and tax authorities, who state that tax treaties will attract foreign investment.

The addition of double taxation treaties between Indonesia and partners from other countries will significantly affect the increase in FDI into Indonesia. These results are also consistent with the results of the research of Neumayer (2007), which shows that developing countries that have double taxation treaties with more developed countries are benefited by getting a higher flow of FDI. In addition to P3B, other factors that have an effect on FDI in Indonesia are GDP per capita, political conditions and the availability of natural resources, mining, oil and gas fields. P3B is a major factor in increasing FDI in Indonesia compared to the GDP factor, resources rent and political conditions. Although these three factors also significantly affect FDI in Indonesia, the presence or absence of P3B with certain countries is a major consideration for investors of other countries when deciding on their capital investment in Indonesia. 
In order to attract more foreign investors from developed countries and others, governments should renegotiate or amend the P3B that exists today. Its goal is to provide optimum benefits for the Indonesian economic condition. The Indonesian government and the other parties concerned should start to consider adding a new partner of P3B, especially from countries that have substantial investments around the world, and particularly in Indonesia, such as Brazil, Ireland and Chile.

The government, in this case the executive, is expected to maintain a stable political condition by maintaining a good relationship with the legislature, either with the DPR or with the MPR agency. In addition, the government should improve the condition of the national economy, by creating policies that can create a good business climate and provide incentives in accordance with current conditions in the mining, oil and gas industries. Hence, it will give a sense of security and stability to existing foreign investors and will attract other investors to invest in Indonesia. The government is expected to provide legal certainty in the field of taxation, by making new regulations that support it, and also to build awareness by the tax authorities in Indonesia to obey the rules in a treaty agreement.

\section{REFERENCES}

A. Easson, (2000). Do We Still Need Tax Treaties?, 54 Bull. Intl. Fiscal Docn. 12, pp. 619-625, Journals IBFD. Ariyanti. (2015). Sering Digugat Pemerintah Jokowi Revisi Perjanjian Investasi (Often Sued Jokowi Government Revised Investment Agreement). http://bisnis.liputan6.com/read/2229991/sering-digugat-pemerintahjokowi-revisi-perjanjian-investasi.html.

Badan Kebijakan Fiskal Kementrian Keuangan. (2012). Tax Treaty dan Pengaruhnya Terhadap Arus Investasi antara Indonesia dengan Negara-negara Mitra (Tax Treaty and its Influence on Investment Flows between Indonesia and Partner Countries). Pusat Kebijakan Regional dan Bilateral Jakarta.

Barthel, F., Busse, M. \& Neumayer, E. (2010). The impact of double taxation treaties on foreign direct investment: Evidence from large dyadic panel data. Contemporary Economic Policy, 28(3), 366-77. doi:10.1111/j.1465-7287.2009.00185.x.

Blonigen, B., and R, Davies. (2004). The Effect of Bilateral Tax Treaties on U.S FDI Activity. International Tax and Public Finance.

Blonigen, B.A. and Davies, R.B. (2005), "Do Bilateral Tax Treaties Promote Foreign Direct Investment?", in Choi/Hartigan (eds.) Handbook of International Trade, Volume II (London: Blackwell), pp. 526-546.

Coupé, Tom, Irina Orlova, and Alexandre Skiba, 2008, The Effect of Tax and Investment Treaties on Bilateral FDI Flows to Transition Countries, mimeo.

Danny Darussalam Tax Consulting. (2016). www.dannydarussalam.com. Retrieved from www.dannydarussalam.com.

Davies, R. (2003), Tax Treaties, Renegotiations, and Foreign Direct Investment, Economic Analysis \& Policy 33(2), pp. 251-273.

Di Giovanni, J. (2005). "What Drives Capital Flows? The Case of Cross-border M\&A Activity and Financial Deepening", 65 Journal of International Economics 1, pp. 127-149.

Egger, P., Larch, M., Pfaffermayr, M., and Winner, H. (2006), "The Impact of Endogenous Tax Treaties on Foreign Direct Investment: Theory and Evidence”, 39 Canadian Journal of Economics 3, pp. 901-931.

Gunadi. (1997). Pajak Internasional. Jakarta: Lembaga Penerbit UI.

Loncarevic, I. (2005). Economic relevance of double taxation conventions. In M. Stefaner \& M. Zuger (Eds.), Tax treaty policy in development. Austria: Linde Verlag.

Neumayer, E. (2007). Do double taxation treaties increase foreign direct investment to developing countries? Journal of Development Studies, 43(8), 1501-1519.

Rahayu, N. (2008). Praktik Penghindaran Pajak (tax avoidance) pada foreign direct investment Yang Berbentuk subsidiary company (PT. PMA) Di Indonesia (Suatu Kajian Tentang Kebijakan anti tax avoidance) (Tax Avoidance Practices in the Foreign Direct Investment of a Subsidized Company (PT PMA) In Indonesia (An Anti Tax Avoidance Policy)) (Published Dissertation). Universitas Indonesia. http://lib.ui.ac.id/ opac/themes/libri2/detail.jsp?id $=121296 \&$ lokasi $=$ local.

Sophia. (2013). Konsep Dasar Pajak Internasional (Basic Concepts of International Tax). http://sophiaririnkali.blogspot.com/2013/05/konsep-dasar-pajak-internasional.html.

Surrey, Stanley. (1980), United Nations model convention for tax treaties between developed and developing countries: a description and analysis, Amsterdam: IBFD.

UNCTAD. (2015). World investment report. http://unctad.org/en/PublicationsLibrary/wir2015_en.pdf

World Bank. (2016). World development indicators. http://data.worldbank.org/data-catalog/ world-development-indicators. 